\title{
PEMBELAJARAN THINKING ACTIVELY IN SOCIAL CONTEXT UNTUK MENINGKATKAN KEMAMPUAN HIGHER ORDER THINKING SISWA SMA
}

\author{
Irma Yuniar Wardhani \\ INSTITUT AGAMA ISLAM NEGERI KUDUS \\ Email: irmaywardhani@gmail.com
}

\begin{abstract}
ABSTRAK
Penelitian ini bertujuan untuk mengembangkan model pembelajaran Thinking Actively in Social Contexts (TASC) pada pembelajaran Biologi SMA disertai dengan panduan model yang layak untuk meningkatkan kemampuan higher order thinking. Penelitian ini menggunakan model 4D: define, design, develop, disseminate yang dikombinasikan dengan model Borg and Gall. Tahap define meliputi analisis kurikulum, karakteristik siswa, kegiatan siswa, materi dan tujuan pembelajaran. Tahap design meliputi pemilihan media, perancangan modifikasi sintaks, perancangan format panduan model, serta pembuatan produk awal. Tahap develop meliputi pengembangan model TASC disertai panduan model dengan penilaian oleh ahli dan uji pengembangan (uji coba terbatas dan uji coba lapangan). Tahap disseminate merupakan upaya penyebaran model TASC dilengkapi panduan model yang telah direvisi kepada beberapa pihak terkait. Hasil penelitian menunjukkan bahwa model pembelajaran TASC layak dan efektif untuk meningkatkan kemampuan higher order thinking siswa. Pencapaian nilai kemampuan higher order thinking mengalami peningkatan yang signifikan berdasarkan hasil pretest dan postes yang telah diuji dengan uji gain score dan uji $t$.
\end{abstract}

Kata kunci: TASC, kemampuan higher order thinking.

\begin{abstract}
This study aims to develop the qualified Thinking Actively in Social Contexts (TASC) learning model and the guidelines on Biology to improve higher order thinking skills. The design of the study used the 4D model consisted of: define, design, develop, and disseminate which combined with the model suggested by Borg and Gall. The defining phase included the analyses of curriculum, students' characteristics, students' activity, materials, and learning objectives. The designing phase included media selection, designing format of the
\end{abstract}


guidelines, and producing the initial product. The developing phase included developing the TASC learning model and guidelines with an assessment by an expert, and developing a test (limited trial and expanded trial). The disseminating phase was an effort to distribute the revised TASC learning model and the guideline to some of the parties concerned. The results show that TASC learning model and the guidelines are qualified and effective to improve higher order thinking skills. The achievement in higher order thinking skills of students has increased quite significantly based on the results of the pretest and posttest that shown by the gain score test and t-test.

Keywords: TASC, higher order thinking skills.

\section{PENDAHULUAN}

Kurikulum pendidikan di Indonesia bertujuan untuk meningkatkan kecerdasan, pengetahuan, kepribadian, akhlak mulia, serta keterampilan untuk hidup mandiri. Selain itu, salah satu karakteristik dari kurikulum tersebut yaitu mengacu pada keragaman potensi daerah, karakteristik daerah dan lingkungan sekitar. Sejalan dengan hal tersebut, pembelajaran disusun dengan memperhatikan potensi, tingkat perkembangan, minat, kecerdasan intelektual, emosional dan sosial, spiritual dan kinestetik peserta didik. Oleh karena itu, pendidikan dewasa ini menuntut pengembangan keterampilan pribadi, keterampilan sosial, keterampilan akademik dan keterampilan berpikir. Pada implementasinya, pembelajaran diarahkan untuk melatih siswa agar mempunyai kompetensi berpikir analitis, induktif dan deduktif untuk menyelesaikan permasalahan yang berkaitan dengan kehidupan sehari-hari.

Berdasarkan hasil analisis kebutuhan pada siswa SMA di beberapa sekolah di Daerah Istimewa Yogyakarta menunjukkan sebesar 28,62\% kemampuan higher order thinking siswa masih berada dibawah rata-rata. Hal tersebut memperlihatkan perlunya peningkatan kemampuan higher order thinking dalam pembelajaran Biologi. Hasil tersebut sejalan dengan penelitian Istiyono (2014: 42) yang menunjukkan bahwa kemampuan berpikir tingkat tinggi yang meliputi kemampuan menganalisis, mengevaluasi dan mencipta pada siswa kelas XI SMA di Daerah Istimewa Yogyakarta belum memuaskan, yaitu sekitar 49\% siswa berada di bawah kemampuan rata-rata. 
Perlunya peningkatan kemampuan berpikir tingkat tinggi juga dapat dilihat berdasarkan data dari Trends in Mathematics and Science Study (TIMSS) yang diadakan oleh International Association for the Evaluation of Educational Achievement (IEA). Penilaian TIMSS terhadap kemampuan kognitif meliputi domain pengetahuan, domain penerapan dan domain penalaran yang didalamnya termasuk kemampuan berpikir tingkat tinggi. Hasil TIMSS 2011 pada bidang sains (IPA) menunjukkan Indonesia memperoleh nilai 406, nilai ini berada di bawah nilai rata-rata internasional yaitu 500. Kemampuan kognitif siswa yang masih di bawah rata-rata menunjukkan bahwa kemampuan berpikir tingkat tinggi siswa masih perlu ditingkatkan.

Menurut Brookhart (2010: 3) kemampuan higher order thinking merupakan kemampuan mengaplikasikan pengetahuan dan ketrampilan yang dimiliki untuk kemudian dikembangkan dalam pembelajaran melalui berpikir kritis dalam pemecahan masalah. Sedangkan, Forster (2004: 2) menjelaskan tentang konsep higher order thinking merupakan suatu proses berpikir yang dibutuhkan untuk memecahkan masalah dan membuat keputusan dalam kehidupan sehari-hari.

Kemampuan berpikir tingkat tinggi dapat ditumbuhkan dengan mengarahkan peserta didik untuk terlibat aktif dalam aktivitas sosial. Aktivitas sosial sebagai salah satu jenis aktivitas peserta didik dalam pembelajaran merupakan hal yang perlu diperhatikan oleh pendidik. Aktivitas sosial yang dilakukan secara berkesinambungan akan menumbuhkan keterampilan sosial ( social skills) yang penting dimiliki oleh peserta didik.

Welsh et al., (2001: 478) menjelasakan bahwa hasil penelitian mengenai hubungan antara keterampilan sosial dan kemampuan akademik dari masa ke masa secara konsisten menunjukkan bahwa kedua faktor tersebut saling mempengaruhi satu sama lain. Dengan demikian, dapat dikatakan bahwa peserta didik dengan keterampilan sosial yang baik akan memiliki kemampuan akademik yang baik pula.

Peneliti berupaya untuk mengembangkan model pembelajaran yang dapat meningkatkan kemampuan higher order thinking dengan melibatkan peserta didik dalam aktivitas sosial berbasis lingkungan. Hasil penelitian Sugiarto dan Djukri 
(2015: 10) menunjukan bahwa pembelajaran berbasis lingkungan dapat meningkatkan kreativitas siswa dalam memecahkan permasalahan. Kemampuan berpikir tingkat tinggi dalam penelitian ini meliputi tiga aspek penting, yaitu: (1) kemampuan berpikir analitis; (2) kemampuan berpikir evaluatif; (3) kemampuan berpikir mencipta.

Menurut Anderson et al. (2015: 120), berpikir analitis merupakan kemampuan untuk menguraikan materi atau konsep menjadi beberapa bagian, menentukan hubungan antar bagiannya, atau hubungan antara setiap bagian dengan struktur atau tujuan secara keseluruhan. Kemampuan berpikir analitis dalam penelitian ini memiliki tiga indikator, yaitu: (1) kemampuan membedakan; (2) mengidentifikasi masalah/ hubungan suatu fenomena dengan fenomena lainnya; (3) menentukan/ memberikan ciri khusus terhadap suatu objek pengamatan atau suatu permasalahan.

Kemampuan evaluatif merupakan salah salah satu aspek kognitif yang menunjukkan tingkat kemampuan higher order thinking. Brookhart (2010: 41) menjelaskan bahwa mengevaluasi berarti menilai suatu materi atau metode untuk tujuan tertentu, berdasarkan kriteria tertentu. Kriteria tersebut ditentukan oleh peserta didik. Standar-standar yang digunakan dapat bersifat kualitatif maupun kuantitatif (Anderson et al., 2015: 127). Indikator mengukur evaluasi sebagaimana yang dicantumkan oleh Anderson et al. (2015: 127) meliputi checking (memeriksa) dan critiquing (mengkritik)

Masalah adalah bagian yang mendasar dari proses mencipta. Pada dasarnya setiap individu menciptakan masalah untuk diselesaikan. Mencipta sama dengan problem solving (Monahan, 2002: 49). Kemampuan mencipta merupakan kemampuan berpikir meliputi indikator: (1) generating (kemampuan menemukan sesuatu); (2) planning (kemampuan merencanakan); (3) producing (kemampuan menghasilkan/melaksanakan rencana) (Anderson et al., 2015: 84).

Pada pembelajaran biologi, guru sebenarnya sudah menerapkan metode untuk meningkatkan kemampuan berpikir siswa yaitu dengan tanya jawab dan memberikan latihan soal. Akan tetapi, perlu diketahui bahwa untuk meningkatkan kemampuan berpikir tingkat tinggi, tidak hanya melalui tanya jawab dan latihan soal tetapi siswa juga perlu diberi suatu kasus atau permasalahan yang sesuai 
dengan kehidupan siswa sehari-hari yang bersifat social context. Dengan demikian, siswa memiliki kesempatan untuk mengeksplorasi diri sehingga kemampuan untuk berpikir siswa akan semakin berkembang.

Salah satu alternatif dari kesenjangan permasalahan di atas adalah dengan mengembangkan model pembelajaran Thinking Actively in Social Context (TASC) yang bisa diterapkan oleh guru di sekolah menengah atas untuk meningkatkan kemampuan berpikir tingkat tinggi siswa. TASC memiliki empat elemen penting yang berakar pada pengembangan kurikulum berbasis thinking skills dan problem solving bagi jenjang pendidikan menengah, yaitu thinking, actively, social dan context (Wallace dan Bentley, 2002: 7).

Model TASC sejalan dengan taksonomi Bloom dan metode ilmiah, model ini melatih siswa untuk melakukan penyelidikan (investigating) dan memecahkan masalah (problem solving). Model ini melatih siswa menggunakan lower dan higher order thinking skills yang dimilikinya sehingga siswa akan memiliki pengalaman belajar yang lengkap (Seeley, 2012: 3). Terkait dengan pembelajaran problem solving, hasil penelitian Pardjono (2009: 268) menunjukan bahwa pembelajaran berbasis pemecahan masalah (problem solving) dapat meningkatkan kemampuan kognitif tingkat tinggi siswa berupa kemampuan analisis, sintesis dan evaluasi. Sedangkan menurut Sternberg dan Grigorenko (2010: 55) menyatakan bahwa dalam memecahkan masalah dan pengambilan keputusan memerlukan kemampuan berpikir tingkat tinggi. Survei terakhir yang dilakukan oleh Wallace (2007: 1) menunjukkan lebih dari 10.000 kelas di Inggris telah menggunakan TASC untuk meningkatkan kemampuan berpikir siswa.

Penelitian ini bertujuan untuk mengetahui kelayakan model TASC yang dikembangkan untuk meningkatkan kemampuan higher order thinking siswa, mengetahui pengaruh model TASC yang dikembangkan terhadap kemampuan higher order thinking siswa dalam pembelajaran Biologi, dan mengetahui pencapaian nilai kemampuan higher order thinking siswa setelah menerapkan model pembelajaran TASC. 


\section{METODE PENELITIAN}

Penelitian ini merupakan jenis penelitian dan pengembangan (R\&D). Model pengembangan mengadaptasi dari tipe 4-D yang dikembangkan oleh Thiagarajan dan dikombinasikan dengan model Borg and Gall pada tahap uji coba terbatas. Penelitian dilakukan pada bulan November 2014 - Maret 2015 di SMA Negeri 6 Yogyakarta, SMA Negeri 1 Depok dan SMA Negeri 1 Sanden.

Subjek penelitian ini adalah siswa SMA yang terdiri dari kelas $\mathrm{X}$ dan kelas XI SMA. Subjek uji coba pada tahap pertama atau uji coba skala kecil melibatkan 9 siswa dari kelas X dan 20 siswa kelas XI. Sedangkan subjek uji coba tahap kedua atau uji coba lapangan melibatkan 56 siswa kelas X dan 124 siswa kelas XI. Subjek penelitian dipilih dengan cara random sampling.

Tahapan pengembangan mencakup define, design, develop dan disseminate. Pada tahap define berisi: (1) analisis awal-akhir (Front-End Analysize) untuk mengetahui masalah yang mendasari penelitian dengan telaah kurikulum tentang standar isi, standar proses, standar penilaian dan teori belajar yang relevan serta juga dilakukan pencermatan terhadap masalah pembelajaran yang ada di kelas yaitu perlunya peningkatan kemampuan higher order thinking siswa dan keadaan lingkungan sekitar sekolah; (2) analisis siswa (Learner Analysize) untuk mengetahui karakteristik siswa SMA N 6 Yogyakarta yang rata-rata memiliki kemampuan akademik sedang terutama dalam pembelajaran Biologi; (3) analisis tugas (Task Analysize) untuk memperoleh rincian mengenai tugas-tugas apa saja yang harus dilakukan siswa dalam pembelajaran; (4) analisis konsep/materi untuk memperoleh susunan materi pembelajaran secara sistematis; (5) spesifikasi tujuan pembelajaran (Specifying Instructional Objectives) untuk memperoleh indikator ketercapaian SK/KD materi berdasarkan analisis materi yang telah disusun sebelumnya. Pada tahap design meliputi: proses milihan media (media selection) berupa lembar kegiatan TASC Wheel dan video pembelajaran, pemilihan format (format selection), desain awal (initial design). Pada tahap develop bertujuan untuk menghasilkan model pembelajaran TASC disertai panduan model yang berkualitas (valid, praktis, dan efektif), tahapan ini meliputi: validasi ahli (expert appraisal) untuk mendapatkan pengesahan dari ahli terhadap kevalidan produk dan perangkat pembelajaran yang didesain, melakukan uji pengembangan melalui 
uji coba terbatas dan uji coba lapangan. Tahap terakhir disseminate bertujuan untuk menyebarluaskan produk hasil dari penelitian. Model pembelajaran TASC dilengkapi dengan panduan model bertujuan agar memiliki manfaat bagi masyarakat terutama dikalangan pendidikan dan pemerintah selaku pemangku kebijakan pendidikan.

Pada penelitian ini, peneliti telah melakukan modifikasi dalam beberapa sintaks TASC guna menyesuaikan dengan iklim pembelajaran terutama berkaitan dengan kurikulum yang ada di Indonesia, karakteristik siswa SMA dan materi pelajaran biologi di SMA. Teori yang mendasari pengembangan model pembelajaran TASC untuk mata pelajaran Biologi di SMA yaitu teori perkembangan kognitif Piaget dan Bruner. Menurut Piaget, terdapat empat tahap perkembangan kognitif peserta didik yaitu: tahap sensorimotorik (usia 0-2 tahun), tahap praoperasional (usia 2-6 tahun), tahap operasional konkrit (usia 6-12 tahun) dan tahap formal yang bersifat internal (usia $12 \mathrm{ke}$ atas). Siswa SMA telah memasuki tahap formal yang artinya anak sudah mampu berpikir abstrak dan logis dengan mengembangkan pola berpikirnya. Model berpikir ilmiah sudah mulai dimiliki anak dengan kemampuan menarik kesimpulan, menafsirkan dan mengembangkan hipotesis. Pada tahap ini kondisi berpikir anak sudah dapat bekerja secara efektif dan sistematis, berpikir secara proporsional, menganalisis suatu masalah dan menarik generalisasi (Budiningsih, 2004: 39).

Berkaitan dengan hal tersebut, Bruner juga menjelaskan tahap perkembangan kognitif anak meliputi tahap enaktif, tahap ikonik dan tahap simbolik. Model pembelajaran TASC yang dikembangkan telah dilengkapi dengan Lembar Kegitan TASC Wheel yang dapat membantu siswa mencapai tahap simbolik (Budiningsih, 2004: 40). Berdasarkan kajian beberapa literatur dan saran dari pembuat model TASC yaitu Belle Wallace, maka sintaks dari model TASC yang dikembangkan terdiri dari lima langkah pembelajarandapat dilihat di Tabel 1.

Tabel 1. Tahapan Pengembangan Model TASC

\begin{tabular}{lccc}
\hline \multicolumn{1}{c}{ Sintaks Asli } & Revisi I & Revisi II & Revisi III \\
\hline 1. Gather and & 1. Gather and & 1. Kumpulkan/ & 1. Gather, Organize \\
Organize & Organize & Organisasikan & and Identify \\
2. Identify & 2. Identify & 2. Identifikasi & 2. Decide and Plan
\end{tabular}



3. Generate
3. Generate and Decide
3. Memunculkan ide dan
3. Implement
4. Decide
4. Implement putuskan
4. Terapkan
4. Evaluate and
Communicate
5. Implement
5. Evaluate
5. Evaluasi pekerjaan
5. Learn from
Experince
6. Evaluate
6. Presetation
7. Communicate
7. Reflection and Conclusion
6. Presentasi
7. Refleksi dan Simpulan
8. Learn from
Experince

Model pembelajaran TASC yang dikembangkan dalam penelitian ini merupakan model pembelajaran yang dapat mengasah kemampuan berpikir siswa, khususnya kemampuan higher order thinking melalui pembelajaran yang berbasis social context dengan lingkungan sebagai sumber belajar bagi siswa sehingga siswa akan lebih mudah dan tertarik dalam memahami konsep-konsep dalam pembelajaran biologi. Model pembelajaran yang dikembangkan peneliti terdiri dari lima sintaks, yaitu: (1) Gather, Organize dan Identify; (2) Decide; (3) Implement; (4) Evaluate dan communicate; (5) Learn from Experience. Kelima sintaks tersebut telah disesuaikan dengan iklim pembelajaran terutama berkaitan dengan kurikulum yang ada di Indonesia dan karakteristik siswa SMA yang ada di Indonesia.

Berkaitan dengan sintaks/ langkah-langkah dalam model pembelajaran $T A S C$, maka selain mengembangkan sintaks pembelajaran peneliti juga membuat lembar TASC Wheel untuk memudahkan siswa dalam belajar, sehingga siswa akan memiliki pola pikir yang baik dan runut mulai dari mengidentifikasi masalah, menganalisis dan menyelesaikan permasalahan yang dihadapi. Lembar Kegiatan TASC Wheel dicetak dengan ukuran A3 sehingga memudahkan keterbacaan dan pengisian bagi siswa.

Teknik yang digunakan dalam pengambilan data yaitu: teknik dokumentasi, teknik quesioner, teknik tes, dan teknik observasi. Teknik dokumentasi digunakan untuk mendapatkan nilai Ujian Semester kelas X dan XI semester gasal tahun pelajaran 2014/2015 mata pelajaran biologi yang digunakan untuk uji keseimbangan antara kelas kontrol dan kelas eksperimen. Teknik observasi digunakan untuk mengukur keterlaksanaan sintaks model TASC yang diterapkan 
pada pembelajaran biologi. Teknik angket digunakan untuk mengetahui kepraktisan model TASC bagi guru dan siswa, sedangkan teknik tes digunakan untuk mengetahui keefektifan model pembelajaran TASC dalam meningkatkan kemampuan higher order thinking siswa. Instrumen pengumpulan data dalam penelitian ini terdiri dari: lembar validasi, lembar penilaian kepraktisan oleh guru dan siswa, lembar observasi keterlaksanaan sintaks, dan tes higher order thinking. Teknik analisis data yang dilakukan adalah teknik analisis data kuantitatif dan kualitatif. Data kuantitatif dianalisis menggunakan uji-t, sedangkan kualitatif dianalisis menggunakan konversi skor menurut Azwar (2014: 163)

Analisis data kevalidan mencakup masing-masing komponen produk yang dikembangkan, yaitu validasi model pembelajaran TASC untuk Biologi SMA, RPP dan tes kemampuan higher order thinking. Analisis data kepraktisan meliputi dua hal, yaitu penilaian dari guru dan siswa tentang kepraktisan penggunaan model pembelajaran TASC untuk kelas SMA, dan hasil observasi keterlaksanaan pembelajaran menggunakan model TASC. Kepraktisan model pembelajaran dalam penelitian ini dilihat dari konsistensi penilaian dari kedua sumber tersebut.

Analisis data untuk menentukan keefektifan model pembelajaran TASC yang dihasilkan dilakukan dengan cara mengolah data hasil tes belajar yang diperoleh siswa pada kelas kontrol dan kelas eksperimen yang berupa tes kemampuan higher order thinking. Produk hasil pengembangan berupa model pembelajaran TASC dikatakan efektif digunakan dalam proses pembelajaran biologi apabila terdapat peningkatan yang signifikan kemampuan higher order thinking berdasarkan hasil pretest-posttest dan persentase nilai rata-rata kelas minimal 70\% berdasarkan kategori efektif menurut Akbar (2013: 82). Untuk mengetahui adanya peningkatan hasil pretest-postest kemampuan higher order thinking siswa dilakukan dengan uji-t dan analisis gain score.

Sebelum melakukan eksperimen dengan menggunakan kelas kontrol dan kelas ekperimen, maka terlebih dahulu dianalisis data hasil Ujian Semester siswa untuk mengetahui apakah kemampuan siswa sebelum perlakuan antara kelas kontrol dan kelas eksperimen sama (setara) melalui uji keseimbangan. Uji keseimbangan dilakukan pada saat kedua kelompok sebelum dikenai perlakuan bertujuan untuk mengetahui apakah kedua kelompok tersebut seimbang. Sebelum 
uji-t, dilakukan uji prasyarat yaitu uji normalitas menggunakan uji kolmogorofsmirnov dan uji homogenitas menggunakan uji Levene's dengan SPSS 21.

\section{HASIL DAN PEMBAHASAN}

Produk yang dihasilkan berupa model pembelajaran TASC pada pembelajaran Biologi SMA disertai dengan panduan model pembelajaran TASC. Panduan ini dilengkapi dengan RPP, Lembar Kegiatan TASC Wheel dan tes kemampuan higher order thinking. Produk yang dikembangkan masing-masing harus memenuhi kriteria valid, praktis dan efektif.

Kegiatan validasi dilakukan dengan cara menyerahkan produk awal beserta komponen pendukungnya kepada validator/ ahli untuk diberikan skor berkaitan dengan kevalidan hasil pengembangan berupa model pembelajaran TASC untuk SMA. Berdasarkan hasil validasi diketahui bahwa masing-masing komponen perangkat pembelajaran yang dihasilkan berupa panduan model TASC, RPP dan tes kemampuan higher order thinking memenuhi kategori valid. Uji keterbacaan Lembar Kegiatan TASC Wheel sebagai salah satu komponen pendukung model pembelajaran TASC untuk pembelajaran Biologi dalam penelitian ini berada pada kategori baik dengan persentase kriteria pencapaian lebih dari 70\%. Hal ini berarti Lembar Kegiatan TASC Wheel yang dikembangkan sebagai komponen pendukung model pembelajaran TASC telah layak untuk digunakan.

Model TASC yang dikembangkan dikatakan praktis dan efektif jika praktisi/ guru menyatakan bahwa model TASC mudah dalam mengimplementasikannya di kelas dan tingkat keterlaksanaan model termasuk dalam kategori baik serta tujuan pembelajaran biologi yang direncanakan tercapai dengan baik. Indikator untuk menyatakan bahwa keterlaksanaan model pembelajaran ini dikatakan "baik" adalah dengan melihat apakah setiap sintaks model dapat dilaksanakan dengan baik oleh guru dalam pembelajaran di kelas.

Pengambilan data hasil observasi keterlaksanaan pembelajaran dilakukan sebanyak 3 (tiga) kali dalam proses pembelajaran di kelas. Observasi dilakukan oleh peneliti sebagai observer pada setiap pertemuan di kelas. Data hasil observasi keterlaksanaan pembelajaran model TASC disajikan pada Tabel 2. 
Tabel 2. Hasil Analisis Kepraktisan Berdasarkan Keterlaksanaan Pembelajaran

\begin{tabular}{|c|c|c|c|}
\hline \multirow{2}{*}{$\begin{array}{c}\text { Langkah-langkah } \\
\text { pembelajaran } \\
\text { model TASC }\end{array}$} & \multicolumn{3}{|c|}{$\begin{array}{l}\text { Prosentase keterlaksanaan } \\
(\%) \text { pada pertemuan ke- }\end{array}$} \\
\hline & 1 & 2 & 3 \\
\hline $\begin{array}{l}\text { Gather, Organize } \\
\text { and Identify }\end{array}$ & 94 & 100 & 100 \\
\hline DecideandPlan & 81 & 94 & 94 \\
\hline Implement & 88 & 100 & 100 \\
\hline Communication & 81 & 88 & 100 \\
\hline $\begin{array}{l}\text { Learn by } \\
\text { experience }\end{array}$ & 100 & 94 & 94 \\
\hline Rata-rata & 89 & 95 & 98 \\
\hline
\end{tabular}

Berdasarkan hasil analisis pada Tabel 2 dapat dilihat bahwa pada pertemuan pertama sampai pertemuan terakhir keterlaksanaan pembelajaran berkisar antara 89\% sampai 98\%, hal ini menunjukkan bahwa model pembelajaran TASC untuk SMA yang dikembangkan telah mencapai kriteria praktis berdasarkan keterlaksanaan pembelajaran.

Analisis data kepraktisan mencakup dua hal, yaitu (1) analisis data hasil penilaian dari guru dan siswa setelah menggunakan model pembelajaran TASC untuk SMA, dan (2) analisis data hasil observasi keterlaksanaan pembelajaran menggunakan model pembelajaran TASC di kelas. Kepraktisan perangkat pembelajaran dalam penelitian ini dilihat dari konsistensi penilaian berdasarkan hasil analisis data keduanya.

Berdasarkan hasil analisis terhadap data penilaian model pembelajaran oleh siswa diketahui bahwa prosentase siswa yang memberikan penilaian minimal baik sebesar 91,3\%. Sedangkan berdasarkan penilaian guru seluruh aspek pada model pembelajaran TASC yang dikembangkan masuk ke dalam kategori baik. Hal ini menunjukkan bahwa model pembelajaran TASC untuk SMA yang dikembangkan telah mencapai kriteria praktis berdasarkan penilaian guru dan siswa dalam pembelajaran.

Analisis data keefektifan didasarkan pada data tes kemampuan higher order thinking yang meliputi kemampuan berpikir analitis, kemampuan berpikir evaluatif dan kemampuan berpikir mencipta (create). Pengambilan data ini dilakukan 2 (dua) tahap, yaitu sebelum dilakukan pembelajaran dengan model TASC (pretest), dan setelah dilakukan pembelajaran dengan model TASC hasil 
pengembangan (posttest). Untuk mengetahui apakah model pembelajaran TASC berpengaruh terhadap kemampuan higher order thinking siswa maka nilai pretestposttest diuji menggunakan uji-t .

Pada aspek kemampuan berpikir analitis siswa, berdasarkan hasil analisis menggunakan uji-t dengan taraf signifikansi 0,05 diperoleh bahwa terdapat perbedaan yang signifikan antara rata-rata kemampuan berpikir analitis siswa sebelum menerapkan model TASC dengan rata-rata kemampuan berpikir analitis siswa setelah menerapkan model TASC. Hal ini dapat diinterpretasikan bahwa pada tingkat kepercayaan 95\%, rata-rata kemampuan berpikir analitis siswa setelah pembelajaran dengan model TASC (mean $=71,4)$ mengalami peningkatan jika dibandingkan dengan rata-rata kemampuan berpikir analitis siswa sebelum menggunakan model TASC $($ mean $=57,9)$. Kenaikan ini signifikan pada taraf kepercayaan $95 \%$.

Analisis juga dilakukan antara kelas kontrol dan kelas eksperimen dengan menggunakan uji-t terhadap gain score. berdasarkan hasil uji t terhadap gain score kemampuan higher order thinking dihasilkan bahwa terdapat perbedaan yang signifikan antara kemampuan higher order thinking siswa kelas kontrol dengan siswa kelas eksperimen. Berikut disajikan diagram batang perbandingan kemampuan higher order thinking siswa kelas kontrol dan kelas eksperimen pada Gambar 2.

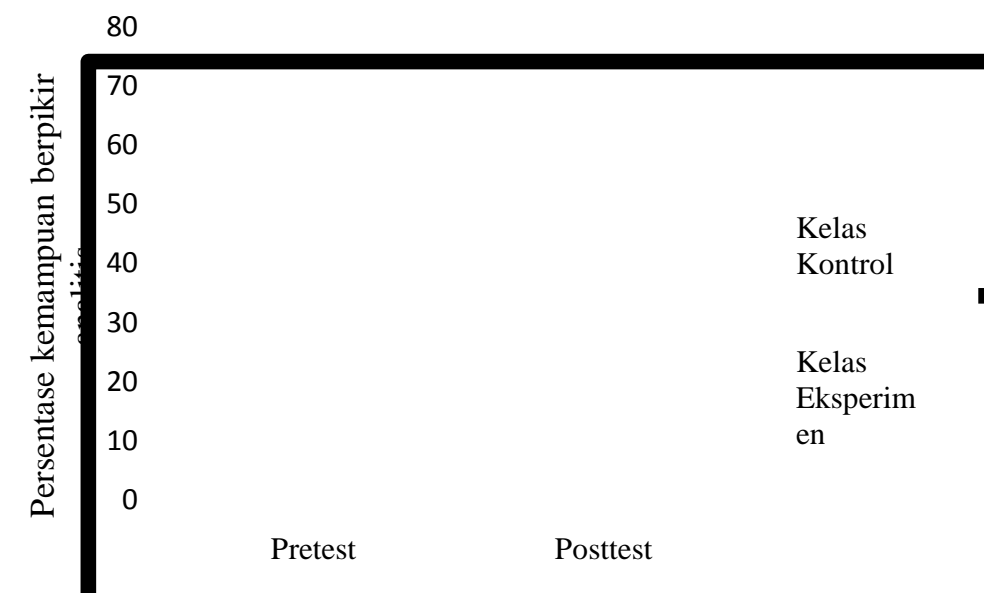

Gambar 2. Diagram Batang Perbandingan Kemampuan Berpikir Analitis Siswa Kelas Kontrol dan Eksperimen. 
Pada aspek kemampuan berpikir evaluatif, berdasarkan hasil uji-t terhadap pretest dan posttest yang telah dilakukan, dapat diketahui bahwa terdapat perbedaan yang signifikan antara rata-rata kemampuan berpikir evaluatif sebelum dengan sesudah menerapkan model TASC. Selain itu, perlu diketahui pula kelas eksperimen dalam penelitian ini memiliki rata-rata nilai kemampuan berpikir evaluatif yang lebih tinggi dibanding dengan kelas kontrol. Rata-rata kemampuan berpikir evaluatif kelas eksperimen sebesar 75,25 dan kelas kontrol sebesar 70,81. Selain itu, pada kelas eksperimen sebesar 78,57\% peserta didik telah mencapai KKM. Pada kelas kontrol, hanya 68,75\% peserta didik yang mencapai KKM.

Pada aspek kemampuan berpikir mencipta, hasil uji hipotesis pada kelas kontrol menunjukkan bahwa pada kelas kontrol nilai signifikansinya lebih dari 0,05 yakni 0,826 artinya tidak ada perbedaan signifikan antara pretest dan posttest. Hasil uji-t pada kelas eksperimen nilai signifikansinya kurang dari 0,05 yakni 0,000 artinya ada perbedaan yang signifikan antara pretest dan posttest. Pembelajaran pada kelas eksperimen dapat dikatakan memberikan dampak pada perubahan kemampuan berpikir mencipta siswa.

Berdasarkan hasil uji gain score diketahui bahwa nilai rata-rata gain score adalah 0,73 artinya masuk dalam kategori tinggi. Terdapat 2 siswa yang gain scorenya masih rendah, sementara itu $92 \%$ siswa gain scorenya sudah baik. Kesimpulan yang dapat diambil adalah penggunaan model pembelajaran TASC ini dapat meningkatkan kemampuan berpikir mencipta siswa secara signifikan. Persebaraan nilai kemampuan berpikir mencipta dapat dilihat pada Tabel 3.

Tabel 3. Persebaran Nilai Kemampuan Berpikir Mencipta

\begin{tabular}{cc}
\hline Kisaran Nilai & Jumlah siswa \\
\hline $90-100$ & 10 \\
$81-90$ & 4 \\
$71-80$ & 8 \\
$61-70$ & 1 \\
$51-60$ & 1 \\
\hline
\end{tabular}

Berdasarkan hasil analisis diketahui pula bahwa kelas kontrol yang menggunakan model pembelajaran yang biasa digunakan oleh guru menunjukkan 
adanya peningkatan meskipun tidak signifikan, hal ini berarti model pembelajaran yang biasa digunakan oleh guru cukup baik digunakan dalam meningkatkan kemampuan berpikir siswa. Namun, tingkat keefektifan model tersebut dalam meningkatkan kemampuan berpikir siswa masih lebih rendah dibandingkan dengan model TASC, hal tersebut dapat dilihat dari gain score dan kenaikan ratarata kelas antara kelas kontrol dan kelas eksperimen. Pada kelas kontrol prosentase peningkatan nilai rata-rata kelas sebesar 9,4\%, sedangkan kelas eksperimen mencapai 13,5\%. Berdasarkan hasil analisis tersebut dapat disimpulkan bahwa model pembelajaran TASC yang dikembangkan peneliti lebih efektif untuk meningkatkan kemampuan higher order thinking siswa.

Hasil pada kelas eksperimen yang menggunakan model pembelajaran TASC menunjukkan peningkatan kemampuan higher order thinking siswa yang tinggi. Peningkatan kemampuan higher order thinking siswa tidak lepas dari keberhasilan model pembelajaran TASC. Hal ini terjadi karena TASC memberikan peluang kepada siswa untuk belajar berdasarkan konteks sosial yang ada di lingkungan mereka. Konteks sosial tersebut dengan mengangkat aktivitas sosial atau permasalahan di lingkungan sekitar sekolah sebagai permasalahan yang harus dipecahkan siswa. Melalui konteks sosial ini siswa lebih mudah memahami materi dan kemampuan higher order thinking siswa akan terlatih untuk menyelesaikan permasalahan-permasalahan di lingkungan sekitarnya.

Hasil penelitian tersebut sejalan dengan teori yang dikemukakan oleh tiga tokoh besar yaitu Sternberg, Vygotsky dan Bandura yang mengusung pembelajaran aktif, baik aktif dalam berpikir maupun aktif dalam berinteraksi dengan lingkungannya sehingga kemampuan berpikir dan kemampuan sosial siswa dapat berkembang dengan baik (Wallace dan Bentley, 2002: 9). Lingkungan sekitar siswa dapat menjadi sumber belajar yang baik untuk mengembangkan kemampuan berpikirnya sehingga siswa dapat memahami konsep lebih matang. Selain itu, hal ini juga sejalan dengan hasil penelitian Balanay dan Roa (2013: 36) yang menjelaskan bahwa cara belajar terbaik bagi siswa yaitu dari pengalaman mereka, siswa memperoleh pengetahuan dan keterampilan melalui pengamatan langsung yang diikuti dengan kegiatan analisis dari apa yang telah dirasakan dan dipahami. 


\section{SIMPULAN}

Produk yang dihasilkan berupa model pembelajaran TASC pada pembelajaran Biologi SMA disertai dengan panduan model untuk pembelajaran TASC. Panduan model dilengkapi dengan Rencana Pelaksanaan Pembelajaran (RPP), lembar kegiatan TASC Wheel dan tes kemampuan higher order thinking. Produk yang dihasilkan masing-masing memenuhi kriteria valid berdasarkan penilaian oleh dosen ahli, sedangkan kriteria praktis dan efektif diperoleh setelah uji coba lapangan berdasarkan penilaian guru/ praktisi dan siswa. Pencapaian nilai kemampuan higher order thinking siswa mengalami peningkatan yang signifikan antara hasil pretest dan posttest berdasarkan hasil paired sample t-test. Oleh karena itu, model TASC layak digunakan untuk meningkatkan kemampuan higher order thinking siswa dalam pembelajaran biologi di SMA.

\section{DAFTAR PUSTAKA}

Akbar, S. (2013). Instrumen Perangkat Pembelajaran. Bandung: Remaja Rosdakarya.

Anderson, L.W., Krathwohl, D.R., Airasian, P.W., Cruikshank, K.A., Mayer, R.E., Pintrich, P.R., Raths, J. \& Wittrock, M.C. (2015). Kerangka Landasan untuk Pembelajaran, Pengajaran, dan Asesmen. Revisi Taksonomi Pendidikan Blook. Diterjemahkan dari: A Taxonomy for Learning, Teaching, and Assessing: A Revision of Bloom's Taxonomy of Educational Objectives, Abridged Edition. Yogyakarta: Pustaka Pelajar.

Azwar, S. (2014). Tes Prestasi: Fungsi dan Pengembangan Pengukuran Prestasi Belajar. Yogyakarta: Pustaka Pelajar.

Balanay, C. A. S. dan RoaE. C. (2013). Assessment on Students'Science Process Skills: A Student- Centred Approach. International Journal of Biology Education Vol. 3, Issue 1, 24-44.

Brookhart, S. (2010). How to Assess Higher Order Thinking Skills in Your Classroom. Alexandria: ASCD.

Budiningsih, A. (2004). Belajar dan Pembelajaran. Yogyakarta: Rineka Cipta.

Dinas Pendidikan DIY. Data Nilai Ujian Akhir Nasional SMA se-DIY Tahun Pelajaran 2013/2014. Yogyakarta: Dinas Pendidikan DIY.

Forster, Margaret. (2004). Higher Order Thinking Skills. Research Developments, Vol. 11, Art. 1. Diakses April 2015 dari http://research.acer.edu.au/resdev/vol11/iss11/1 
Istiyono, E. (2014). Pengukuran Kemampuan Berpikir Tingkat Tinggi Fisika Peserta Didik SMA di DIY. Disertasi Doktor, tidak diterbitkan. PPS Universitas.

Monahan, T. (2002). The Do-it-yourself Lobotomy Open Your Mind to Greater Creative Thinking. New York: John Wiley \& Sons, Inc

Pardjono. (2009). Peningkatan Kemampuan Analisis, Sintesis, dan Evaluasi Melalui Pembelajaran Problem Solving. Jurnal Cakrawala Pendidikan, Tahun XXVIII, No. 3, 257-269.

Seeley, C. (2012). Using The TASC Wheel. Diakses 5 Desember 2013, dari http://suffolklearning.co.uk./do_download.asp?did=3758?.

Sternberg, J. R dan Grigorenko E.L.. (2010). Mengajarkan Kecerdasan Sukses (Terjemahan). Yogyakarta: Pustaka Pelajar.

Sugiarto, A. dan Djukri. (2015). Pembelajaran Berbasis SETS Sebagai Upaya Meningkatkan Kreativitas dalam Pemecahan Masalah Pencemaran Lingkungan. Jurnal Inovasi Pendidikan IPA Pascasarjana UNY, Volume 1, Nomor 1, 1-11. Diakses April 2015 dari http://journal.uny.ac.id/index.php/jipi/article/view/4527.

TIMSS \& PIRLS Internasional Study Center. (2012). TIMSS 2011 Internasional Result In Science. Boston: The TIMSS \& PIRLS Internasional Study Center, Boston College. Diakses 2 Desember 2013, dari http://timss.bc.edu/timss2011/release.html.

Wallace, B. dan Bentley, R. (2002). Teaching Thinking Skills Across the Middle Years. London: David Fulton Publishers. ISBN 1853467677.

Wallace, B. (2007). Thinking Actively in a Social Context. Diakses 5 Desember 2013, dari http://tascwheel.sheffieldclc.net/?page_id=289.

Welsh, M., Parke, R.D., Widaman, K., \& O’Neil, R. (2001). Linkages Between Children's Social and Academic Competence: A Longitudinal Analysis. Journal of School Psychology, 39 (6), 463-481. 